(RESEARCH ARTICLE)

\title{
Factors affecting success in natural regeneration works of cedar (Cedrus libani A. Rich.) In Kas region of Antalya
}

\author{
Halil Baris Ozel 1, Bircan Donduran 2, Erkan Cakmakli ${ }^{3}$ and Hakan Sevik 4,* \\ ${ }^{1}$ Bartin University, Faculty of Forestry Department of Forestry Engineering, Kastamonu, Turkey. \\ ${ }^{2}$ Antalya Regional Directorate of Forestry, Kas Forestry Operation Directorate, Kasaba Forest Sub-District Directorate, \\ Antalya, Turkey. \\ ${ }^{3}$ Gokcebey Forestry Nursery Directorate, Bartin, Turkey. \\ ${ }^{4}$ Kastamonu University, Faculty of Engineering and Architecture, Department of Environmental Engineering, Kastamonu, \\ Turkey.
}

Publication history: Received on 26 April 2020; revised on 05 May 2020; accepted on 07 May 2020

Article DOI: https://doi.org/10.30574/wjarr.2020.6.2.0127

\begin{abstract}
Plants are living things that form the basis of food pyramid, provide numerous products and are considered as the source of life. Many professions such as agriculture, forestry and landscaping work on plant growing. The fast growth of plants is of prime importance since it provides advantage in light and root competition in the areas where plants are grown. For this reason, it is highly important to identify the factors affecting plant development and to change these factors in favour of the target species. In order to achieve this, first of all, the factors affecting the development of the target species in the study area should be known.

In this study, which was carried out in the natural regeneration areas of Taurus Cedar (Cedrus libani A. Rich) found in the Kasaba Forest Sub-District Directorate in Kas region of Antalya, and was prepared as a term project, 3-year-old young cedars naturally grown in different stands were compared in terms of their root collar diameters, seedling length and number of seedlings, and the factors affecting the natural regeneration success were tried to be identified by factor analysis. As a result of the study, it was found that the average root collar diameter was between 2.5 and $4.7 \mathrm{~mm}$, the average seedling length was between 4.5 and $11.3 \mathrm{~cm}$, and the average number of young cedars per square meter was between 6 and 47. When the factors affecting the natural regeneration success were examined, it was found that the factors such as soil moisture, precipitation, amount of organic matter, light intensity and number of healthy seeds were the most important factors that played a role in this success, and that those factors explained $78.32 \%$ of the total variance.
\end{abstract}

Keywords: Taurus cedar; Cedrus libani; Natural regeneration; Growth; regeneration success

\section{Introduction}

Plants are the most important living groups in the world with vital importance for many other living groups, and they are considered as the source of life. In fact, all living life in the world is largely depend on plants, either directly or indirectly [1]. As well as producing the necessary nutrients for other living things through photosynthesis, plants also function in many other ways such as reducing all kinds of air pollution in their environment [2-4], reducing noise [5,6], preventing erosion, balancing the climate and promoting positive effects on people psychologically [7-10]. In addition to these, they are an important economic resource [11,12]. Particularly forests are extremely critical natural resources for many countries including our country.

\footnotetext{
* Corresponding author: Hakan Sevik
} 
Forests are highly effective on community life in terms of versatile use of the products and services they provide. It is obvious that forests are the most important natural resources in preventing global climate change and managing renewable energy resources. Maintaining the continuity of this critical natural resource and preserving the original stand formats are of great importance for the sustainability of the ecological balance. Within this scope, it is necessary to successfully regenerate the pure and mixed forest formats consisting of species, in particular. In natural regeneration works to be carried out for this purpose, the factors affecting success should be well identified on the basis of species, and juvenile dynamics should be introduced from the first years [13].

Our country has highly valuable pure and mixed stand organizations depending on the impacts of different habitat conditions [14]. The Taurus Cedar (Cedrus libani A. Rich.) is the main species forming these organizations. In this study, the juvenile dynamics and the factors affecting the regeneration success in the natural regeneration works of cedar carried out in 3 sections in the Kasaba Forest Sub-District Directorate affiliated to the Kas Forestry Operation Directorate of Antalya were examined.

\section{Material and methods}

\subsection{Material}

Prepared as a term project, this study was conducted in 3 sections located in the natural regeneration areas, which had been selected 3 years ago because of mast seed year, in the Kasaba Forest Sub-District Directorate affiliated to the Kas Forestry Operation Directorate of Antalya (Figure 1). When the physiographic factors of the natural regeneration areas are examined, it is seen that the altitude varies between 1250 and $1400 \mathrm{~m}$. The stand view is south and southeast. The soil conditions are generally well-drained karstic fields, and the soil has alkaline and neutral conditions. The soil depth is highly variable depending on fissured bedrock conditions, and the organic matter content is insufficient in places. Considering the climatic conditions, the relative air humidity ranges between $70 \%$ and $85 \%$, the average temperature is $21.5^{\circ} \mathrm{C}$, and the average precipitation is $653 \mathrm{~mm}$ [15].

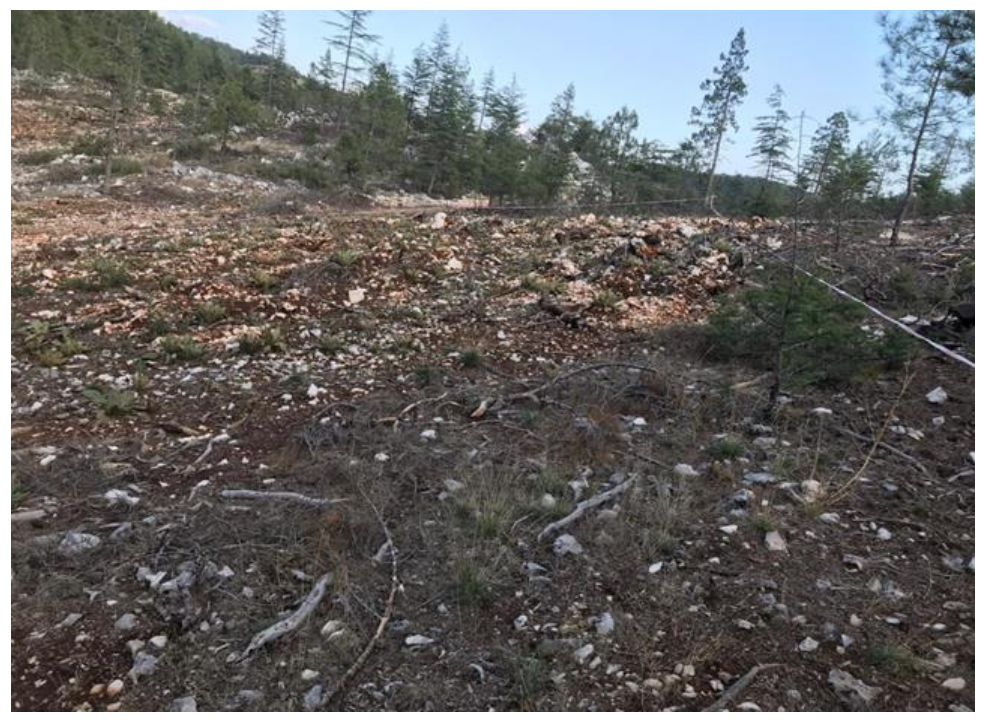

Figure 1 General view of the study area

\subsection{Method}

In the study, in order to identify the growth dynamics of natural young cedars at the end of the third year, the root collar diameters and lengths of the young cedars were measured in 3 sections $(56,123$ and 148) constituting the study area, and the number of young cedar per square meter was determined. In all three sections, the measurements were carried out according to random sampling method, in a way to best represent the physiographic differences in the sections, with 5 replicates in the testing plots with the size of $25 \times 40 \mathrm{~m}$. The measurements were performed with the help of a digital caliper gauge and a length meter with a millimetre precision. Variance analysis and Duncan test were used to evaluate the data obtained from the research. Moreover, factor analysis was used to identify the factors affecting the natural regeneration success. SPSS package program was used for all statistical applications. 


\section{Findings}

The following results were obtained as a result of the measurements carried out in the testing plots selected from the natural regeneration areas of cedar, of which work was carried out in 3 sections of the Kasaba Forest Sub-District Directorate, located in the Kas region of Antalya. Table 1 shows the results of variance analysis and Duncan test applied to the measurements of root collar diameter, seedling length and average number of young cedars taken from the testing plots selected from the 3 sections forming the study area.

Table 1 Variance analysis and Duncan test results on seedling characters

\begin{tabular}{llllll}
\hline Section No & Root Collar Diameter (mm) & Length $(\mathbf{c m})$ & $\begin{array}{l}\text { Number of } \\
\text { (piece/m2) }\end{array}$ & Young & Cedars \\
\hline 56 & $2.5 \mathrm{a}$ & $4.5 \mathrm{a}$ & $6 \mathrm{a}$ & \\
123 & $3.1 \mathrm{~b}$ & $8.9 \mathrm{~b}$ & $34 \mathrm{~b}$ & \\
148 & $4.7 \mathrm{c}$ & $11.3 \mathrm{c}$ & $47 \mathrm{c}$ & \\
Sig. & $\mathrm{P}<0.05$ & $\mathrm{P}<0.05$ & $\mathrm{P}<0.05$ & \\
\hline
\end{tabular}

When the table values are examined, it is seen that the root collar diameter varies between $2.5 \mathrm{~mm}$ and $4.7 \mathrm{~mm}$ in the study area. While the lowest root collar diameter was obtained in section no. 56, the highest root collar diameter was obtained in section no. 148. A similar picture can also be observed in terms of length values. The average seedling length is observed to be $4.5 \mathrm{~cm}$ in the section no. 56, while it is $8.9 \mathrm{~cm}$ in the section no. 123 and $11.3 \mathrm{~cm}$ in the section no. 148 . As for the average number of young cedars, while there is an average of 6 seedlings per $\mathrm{m}^{2}$ in section no. 56, there is an average of 34 seedlings in section no. 123, and an average of 47 seedlings in section no. 148. When the table values are examined, it is seen that there is a significant difference at minimum of $95 \%$ confidence level $(p<0.05)$ between the data in terms of all three characters, and as a result of Duncan test, each value forms a separate homogeneous group.

The main aim of the study is to identify the factors affecting the regeneration success in the natural regeneration works of cedar. Accordingly, physiographic, edaphic and climatic factors as well as the parameters related to the main stand were identified, and the factors were analysed with the help of SPSS program. Among a total of 32 variables, $5 \mathrm{important}$ factors were derived as a result of the factor analysis. These 5 important factors of soil moisture, precipitation, organic matter content, light intensity and number of healthy seeds explained $78.32 \%$ of the total variation in natural regeneration success.

\section{Results and discussion}

There exist highly valuable studies conducted on different fields related to Taurus Cedar, which is one of the most important main forest tree species of our country. First of all, many studies were conducted in order to determine the distribution range of the species under the ecological conditions of our country $[16,17,18]$. In this study, 3 different homogeneous groups were identified in terms of diameter development in the natural regeneration areas of cedar selected from 3 sections of the Kasaba Forest Sub-District Directorate located in the Kas region of Antalya. Accordingly, while the lowest root collar diameter was measured as $2.5 \mathrm{~mm}$, the highest root collar diameter was measured as 4.7 $\mathrm{mm}$ (Table 1). In another study conducted on pure cedar stands in Antalya region, it was found that the average root collar diameter development of 3-year-old natural young cedars varied between 3.8 and $5.8 \mathrm{~mm}$ [19].

Comparing these data, it can be stated that the root collar diameter developments of the natural young cedars in the study area are at a sufficient level. 3 different homogeneous groups were identified in terms of average length growth in the natural regeneration areas of cedar selected from 3 sections of the Kasaba Forest Sub-District Directorate located in the Kas region of Antalya Accordingly, while the lowest average length growth was found to be $4.5 \mathrm{~cm}$, the highest average length growth was found to be $11.3 \mathrm{~cm}$ (Table 1). In a study carried out in the Manavgat region with similar habitat conditions with the study area, it was reported that the average length growth of 3-year-old natural young cedars varied between 5.6 and $14.8 \mathrm{~cm}$ [19]. According to these comparative data, it is possible to say that there is a good growth trend in the study area, despite the occurrence of length growth losses starting from the age 3 due to low bonitet class of the study area.

In this study, the number of young cedars per square meter was also determined as a result of the counts performed in 3 sections. Accordingly, while the lowest average number of young cedars was found to be $6 / \mathrm{m}^{2}$, the highest average 
number of young cedars was $47 / \mathrm{m}^{2}$ (Table 1). In another study conducted on this subject, it was found that the number of natural young cedars varied between 18 and 115 pieces $/ \mathrm{m}^{2}$ at the end of the first 5 years [20]. In the light of these comparative data, it is not possible to say that the number of natural young cedars is at a sufficient level and is homogenous at the end of the $3^{\text {rd }}$ year. It can be said that this situation is caused by insufficient germination of healthy seeds or insufficient moisture or organic matter content.

In the research, the most important factors affecting the success of natural regeneration works of cedar were identified as soil moisture, precipitation, organic matter content, light intensity and number of healthy seeds, and these factors explained $78.32 \%$ of the total variation in natural regeneration success. In other studies conducted on this subject, it is emphasized that soil moisture, soil temperature, and especially the organic matter content in extremely alkaline areas with calcareous bedrock characteristics are of great importance for natural young cedars to come and take root in the area [18].

Plant development occurs as a result of the mutual interaction of genetic structure and environmental conditions [2223]. In natural regeneration works, genetic structure intervention remains limited, and thus the climatic and edaphic factors in the environment, in which the plant is grown, are determinative in plant development. The studies conducted reveal that in our country, plants grown in areas with different climate types have different levels of development depending on the type of that climate [24,25]. Many factors such as precipitation, temperature, stress factors, light, air pollution and soil structure affect the morphological characteristics and development of plants [26-29]. For this reason, identification of the factors affecting the development of each species at the highest level in natural regeneration works, and the arrangements to be made on these factors can contribute to the development of the target species, significantly.

Along with ecological conditions, some external factors also significantly affect plant development and morphological characteristics. The studies conducted reveal that factors such as pruning, hormone applications, spraying, shading, and fertilizing are also effective on plant morphological characteristics and development [30-33]. Therefore, the species can be supported by identifying the effects of also these factors on the species spreading over large areas, and by using these factors especially in sensitive areas, if necessary. For instance, by identifying the fertilizer types that can encourage the growth of cedar seedlings at the highest level, the fertilization applications can be carried out in sensitive areas.

\section{Conclusion}

As a result of the study, first of all, differences were determined between seedling developments in different stands up to several times. Studies to be conducted with the purpose of determining whether the development differences in these areas are due to genetic structure or environmental conditions can contribute to cedar regeneration and breeding practices, significantly.

In the light of the data obtained from the study area, the natural regeneration works of cedar should be carried out in mature stands, which have reached the thick woody stage, and in the correct seed year; the care of young cedars should be carried out in time and according to its technique so the root competition of cedar is decreased; care should be given to protection measures and the soil moisture, organic matter content, soil depth, light intensity and healthy seed number, which constitute the germination bed especially in the firs years, should be checked periodically; and the light demand of young cedars should be well identified and met in time.

Identification of the factors affecting the development of main forest trees, especially cedar, individually and carrying out applications according to these factors in natural regeneration works will affect the success of regeneration significantly and will provide an advantage in light and root competition by contributing to the rapid growth of seedlings at a young age.

Identification of the factors affecting the seedling development as well as their effect levels can also contribute to nursery practices, significantly. The economic value of agricultural plants is directly proportional to their growth performances. While the fast growth of the plants reduces the growing process, and thus the cost, it increases the profit rate. For this reason, identification of the factors affecting seedling development and its use in practice are of great importance. It is recommended to diversify and continue the studies to be conducted on this subject for both natural regeneration works and nursery practices. 


\section{Compliance with ethical standards}

\section{Acknowledgments}

The work was carried out as part of the Antalya Regional Directorate of Forestry, Kas Forestry Operation Directorate, Kasaba Forest Sub-District Directorate, Gokcebey Forestry Nursery Directorate, Bartin University, Faculty of Forestry and Kastamonu University, Faculty of Architecture and Engineering.

\section{Disclosure of conflict of interest}

The authors declare no conflict of interest.

\section{References}

[1] Yigit N, Cetin M, Ozturk A, Sevik H and Cetin S. (2019). Varitation of Stomatal Characteristics in Broad Leaved Species Based on Habitat. Applied ecology and Environmental Research, 17(6), 12859-12868.

[2] Ozel B, Ucun Ozel H and Varol T. (2015). Using Leaves of Oriental Plane (Platanus orientalis L.) to Determine the Effects of Heavy Metal Pollution Caused by Vehicles. Polish Journal of Environmental Studies, 24(6), 2569-2575.

[3] Sevik H, Cetin M, Ozel HB and Pinar B. (2019). Determining toxic metal concentration changes in landscaping plants based on some factors. Air Quality, Atmosphere \& Health, 12(8), 983-991.

[4] Sevik H, Cetin M, Ozel HU, Ozel HB, Mossi MMM and Cetin IZ. (2019). Determination of Pb and Mg accumulation in some of the landscape plants in shrub forms. Environmental Science and Pollution Research, 1-9.

[5] Aricak B, Cetin M, Erdem R, Sevik H and Cometen H. (2020). The usability of Scotch pine (Pinus sylvestris) as a biomonitor for traffic-originated heavy metal concentrations in Turkey. Polish Journal of Environmental Studies, 29(2).

[6] Cetin M, Sevik H and Cobanoglu O. (2020). Ca, Cu, and Li in washed and unwashed specimens of needles, bark, and branches of the blue spruce (Picea pungens) in the city of Ankara. Environmental Science and Pollution Research, 1-10.

[7] Ozel HB and Ertekin M. (2012). The change of stand structure in Uludağ fir (Abies nordmanniana subsp. bornmuelleriana Mattf.) forests along an altitudinal gradient. Kastamonu University Journal of Forestry Faculty, 12(3), 96-104.

[8] Varol T, Emir T, Akgul M, Ozel HB, Acar HH and Cetin M. (2020). Impacts of Small-Scale Mechanized Logging Equipment on Soil Compaction in Forests. Journal of Soil Science and Plant Nutrition, 1-11.

[9] Varol T, Ertuğrul M, Özel HB, Emir T and Çetin M. (2019). The effects of rill erosion on unpaved forest road. Applied Ecology and Environmental Research, 17(1), 825-839.

[10] Ertugrul M, Ozel HB, Varol T, Cetin M and Sevik H. (2019). Investigation of the relationship between burned areas and climate factors in large forest fires in theÇanakkaleregion. Environmental monitoring and assessment, 191(12), 737.

[11] Tunçtaner K, Özel HB and Ertekin M. (2007). Bartın Yöresindeki Ağaçlandırma Alanlarında Kullanılan Yerli ve Yabancı Türlerin Adaptasyon Yetenekleri Üzerine Araştırmalar. Bartın Orman Fakültesi Dergisi, 9(11), 11-225.

[12] Sevik H and Cetin M. (2016). Evaluation of topiary applications and problems: A case study of Kastamonu. International Journal of Multidisciplinary Thought, 5(05), 45-50.

[13] Oliver CD and Larson BC. (1998). Forest Stand Dynamics, Update Edition, John Wiley \& Sons, New York, 520.

[14] Genc M. (2004). Silviculture Technique, S.D.U Faculty of Forestry, Publication No: 46, Isparta, 357s.

[15] Anonymus. (2016). Antalya-Kas Forestry Operation Directorate, Kasaba Forestry Sun-District Directorate, Detailed Silvcultural Plan, 42.

[16] Akgul ME. (1990). Relationship between the Growth and Ecological Properties of Taurus Cedar (Cedrus libani A. Rich.) Planted Outside of Its Occurrence [Dogal Yayilis Alani Disindaki Agaclandirmalarda Toros Sedirinin Gelisimiyle Ekolojik Ozellikleri Arasindaki İliskiler], International Cedar Symposium, 26-43.

[17] Kantarci MD, Parlakdag S, Pehlivan N, Dogan D, Cetin A and Yenel O. (1990). Application of Prescribed Fire Method in Regeneration of Lebanon Cedar Forests and Ecological Basis of the Cleaning [Sedir Ormanlarinin 
Genclestirilmesinde Yangin Kulturu Yontemi ve Bu Genclestirme Alanlarinda Kultur Bakimi Uygulamalarinin Ekolojik Esaslari], International Cedar Symposium, 461-480.

[18] Cepel N and Zech W. (1990). Relationship Between Nutrition and Height Growth in Ciglikara Cedar Regeneration Areas [Ciglikkara Bolgesi Sedir Genclestirme Alanlarinda Boy Artimi İle Beslenme Arasindaki İliskiler], International Cedar Symposium, 43-53.

[19] Ata C, Demirci A and Yavuz H. (1990). Evaluation of the Cedar Stands Structures and Growth Relationships under the Silvicultural Point of View [Sedir Ormanlarinda Mescere Kuruluslari ve Buyume İliskileri İle Bunlarin Silvikulturel Acidan Degerlendirilmesi], International Cedar Symposium, 447-461.

[20] Boydak M, Eler U and Pehlivan N. (1990). Effects of Prescribed Fire and Some Other Factors on the Regeneration Success of Lebanon cedar (Cedrus libani A. Rich) at Elmali-Antalya Region [Antalya Elmali Yoresi Sedirlerinin (Cedrus libani A. Rich) Genclestirilmesinde Bazi Faktorlerin Basari Uzerine Etkileri], International Cedar Symposium, 409-422.

[21] Hrivnák M, Paule L, Krajmerová D, Kulac S, Sevik H, Turna I, Tvauri I and Gömöry D. (2017). Genetic variation in tertiary relics: the case of eastern-Mediterranean Abies (Pinaceae). Ecol Evol, 7(23), 10018-10030.

[22] Yigit N, Sevik H, Cetin M and Kaya N. (2016). Determination of the effect of drought stress on the seed germination in some plant species. Water stress in plants, 43-62.

[23] Sevik H and Guney K. (2013). Effects of some hormone applications on morphological features of Melissa officinalis L. root cuttings. Soil-Water J, 2(2), 1647-1652.

[24] Cetin M, Sevik H and Yigit N. (2018). Climate type-related changes in the leaf micromorphological characters of certain landscape plants. Environmental monitoring and assessment, 190(7), 404.

[25] Cetin M, Sevik H, Yigit N, Ozel HB, Aricak B and Varol T. (2018) The variable of leaf micromorphogical characters on grown in distinct climate conditions in some landscape plants. Fresenius Environmental Bulletin, 27(5), 32063211.

[26] Turkyilmaz A, Sevik H, Isinkaralar K and Cetin M. (2018). Using Acer platanoides annual rings to monitor the amount of heavy metals accumulated in air. Environmental monitoring and assessment, 190(10), 578.

[27] Sevik H, Cetin M, Ozel HB, Akarsu H and Cetin IZ. (2020). Analyzing of usability of tree-rings as biomonitors for monitoring heavy metal accumulation in the atmosphere in urban area: a case study of cedar tree (Cedrus sp.). Environmental Monitoring and Assessment, 192(1).

[28] Cetin M, Sevik H and Cobanoglu O. (2020). Ca, Cu, and $\mathrm{Li}$ in washed and unwashed specimens of needles, bark, and branches of the blue spruce (Picea pungens) in the city of Ankara. Environmental Science and Pollution Research, 1-10.

[29] Sevik H, Cetin M, Ozel HU, Ozel HB, Mossi MMM and Cetin IZ. (2020c). Determination of Pb and Mg accumulation in some of the landscape plants in shrub forms. Environmental Science and Pollution Research, 27(2), 24232431.

[30] Guney K, Cetin M, Sevik H and Guney KB. (2016). Influence of Germination Percentage and Morphological Properties of Some Hormones Practice on Lilium martagon L. Seeds. Oxidation Communications, 39 (1-II), 466474.

[31] Sevik H, Cetin M, Ozel HB, Ozel S and Zeren Cetin I. (2020). Changes in heavy metal accumulation in some edible landscape plants depending on traffic density. Environmental Monitoring and Assessment, 192, 78.

[32] Yucedag C, Ozel HB, Cetin M and Sevik H. (2019). Variability in morphological traits of seedlings from five Euonymus japonicus cultivars. Environmental monitoring and assessment, 191(5), 285.

[33] Şevik H and Ertürk N. (2015). Effects of drought stress on germination in fourteen provenances of Pinus brutia Ten. seeds in Turkey. Turkish Journal of Agriculture-Food Science and Technology, 3(5), 294-299.

\section{How to cite this article}

Halil BO, Bircan D, Erkan C and Hakan S. (2020). Factors affecting success in natural regeneration works of cedar (Cedrus libani A. RICH.) In kas region of antalya. World Journal of Advanced Research and Reviews, 6(2), 54-59. 